\title{
Influence of TiC Content on Microstructure and Properties of W-30Cu/TiC Composites
}

\author{
Chen Jingbo ${ }^{1}, \quad$ Huang Limei ${ }^{1}, \quad$ Luo Laima ${ }^{1,2}, \quad$ Zan Xiang ${ }^{1,2}, \quad$ Wu Yucheng ${ }^{1,2}$ \\ ${ }^{1}$ Hefei University of Technology, Hefei 230009, China; ${ }^{2}$ National-Local Joint Engineering Research Centre of Nonferrous Metals and \\ Processing Technology, Hefei 230009, China
}

\begin{abstract}
W}-30 \mathrm{Cu} / x \operatorname{TiC}(x=0 \sim 4, \mathrm{wt} \%)$ composite powders were prepared by electroless plating with simplified pretreatment. The composite powders were formed by cold compaction under $400 \mathrm{MPa}$ using a tablet machine and green compactions were sintered at $1300{ }^{\circ} \mathrm{C}$ for $1 \mathrm{~h}$. Micromorphology of the original $\mathrm{W}$ and TiC powders, simple-treated $\mathrm{W}$ and TiC powders, and as-received $\mathrm{W}-30 \mathrm{Cu} / x \mathrm{TiC}(x=0 \sim 4)$ composite powders after electroless plating were characterized by field emission scanning electron microscopy (FE-SEM). Microstructures of the W-30Cu/ $x \mathrm{TiC}(x=0 \sim 4)$ composites were also investigated by FE-SEM. The effect of $\mathrm{TiC}$ content on the properties of $\mathrm{W}-30 \mathrm{Cu} / x \mathrm{TiC}(x=0 \sim 4)$ composites (such as relative density, hardness, electrical conductivity, and compressive strength) were studied. Results show that $\mathrm{W}-30 \mathrm{Cu} / \mathrm{TiC}$ composite powders with uniform structure are obtained by simplified $\mathrm{W}$ and $\mathrm{TiC}$ powder pretreatment, followed by electroless copper plating. When $\mathrm{TiC}$ content is less than $1 \mathrm{wt} \%$, the compressive strength and hardness of composite materials obviously increase and the electrical conductivity of composite materials decreases with $\mathrm{TiC}$ content increasing. However, the electrical conductivity of composite materials is still higher than that of the national standard value. With a certain amount of $\mathrm{TiC}$ content to $\mathrm{W}-30 \mathrm{Cu} / x \mathrm{TiC}(x=0 \sim 4)$ composites, the composites exhibit good comprehensive performance.
\end{abstract}

Key words: simplified pretreatment; electroless plating; $\mathrm{W}-\mathrm{Cu} / \mathrm{TiC}$ composites; performance

W-Cu composite materials are widely used as electrode, contact, electronic packaging, and target materials because of the combined excellent properties of $\mathrm{W}$ and $\mathrm{Cu}$. W-Cu composites exhibit high strength and hardness, good electrical and thermal conductivity, low heat expansion coefficient, arc erosion resistance, high-temperature oxidation resistance, and welding resistance ${ }^{[1-5]}$. Electric contact materials require not only good mechanical and physical performance but also good chemical stability; $\mathrm{W}-\mathrm{Cu}$ composite materials are currently in increasing demands as the electric contact materials ${ }^{[6]}$. TiC has unique properties such as high melting point, high elastic modulus, and extreme hardness ${ }^{[7,8]}$. Dispersed TiC nanoparticles can inhibit grain growth during sintering, hinder grain boundary sliding, and stabilize microstructure when exposed to high temperature. These nanoparticles can act as annihilation points for radiation-induced defects, leading to improved irradiation resistance of materials. Therefore, the hardness, fracture strength, and room-temperature ductility of the $\mathrm{TiC}$ dispersed W-Cu composites were effectively improved ${ }^{[9]}$. Nanopowder can significantly reduce sintering activation energy of the powder, enable the composite powder to exhibit excellent sintering activation, reduce sintering temperature, and shorten the sintering time effectively. Mechanical alloying and precipitation-coating processes were available to prepare superfine/nano composite powders ${ }^{[10-12]}$. The mechanical alloying process produced a detrimental phase on the wear of the milling equipment and media. The precipitation-coating process is very complex and incapable of mass production.

$\overline{\text { Received date: February 14 }}, 2017$

Foundation item: National Magnetic Confinement Fusion Program (2014GB121001); National Natural Science Foundation of China (51474083); China Postdoctoral Science Foundation (51574101); Natural Science Foundation of Anhui Province (1408085QE83, 1508085ME101)

Corresponding author: Luo Laima, Ph. D., School of Materials Science and Engineering, Hefei University of Technology, Hefei 230009, P. R. China, Tel: 0086-551-62901012,E-mail: luolaima@126.com 
Electroless plating is an autocatalytic method in which the reduction of metallic ions in the solution and film deposition can be carried out by oxidizing the present chemical compound in the solution. Basic requirements for an electroless bath include metal ions/their concentration, reducing agent(s), complexing agent(s), bath stabilizer(s), and control of $\mathrm{pH}$ and temperature. In electroless deposition, metal ions were reduced to metal by the action of chemical reducing agents which were simple electron donors. The metal ions were electron acceptors that react with electron donors ${ }^{[13,14]}$. The method does not require a current supply and sets no limits on the shape and type of substrate. Electroless plating produced composite powder with even phase dispersion and high purity. Many types of composite powder, including $\mathrm{Ni}-\mathrm{WC}, \mathrm{Ag}-\mathrm{Al}_{2} \mathrm{O}_{3}, \mathrm{Co}-\mathrm{Al}_{2} \mathrm{O}_{3}, \mathrm{Ni}-\mathrm{Cr}_{3} \mathrm{C}_{2}$, $\mathrm{Cu}-\mathrm{Ag}$, and $\mathrm{Ni}-\mathrm{W} / \mathrm{SiC}$, had been successfully prepared in the past through electroless plating ${ }^{[15-20]}$. Interactions of $\mathrm{W}-\mathrm{Cu}$ and $\mathrm{TiC}-\mathrm{Cu}$ are weak to enable excellent catalytic activity on the surface of the powder to be coated in case of uneven coating, rough coating layer, poor tightness, and even difficult coating. Pretreatment of $\mathrm{W}$ and $\mathrm{TiC}$ should be performed prior to electroless plating. Precious metal activation is a pretreatment method that produces the optimal results. However, the cost of this method is high because of the high price of palladium and other precious metals ${ }^{[21,22]}$.

The present paper aimed to study the influence of $\mathrm{TiC}$ contents on microstructure, relative density, hardness, and compressive strength of $\mathrm{W}-\mathrm{Cu}$ composite after simplified pretreatment of $\mathrm{W}$ and $\mathrm{TiC}$ powders at room temperature.

\section{Experiment}

Simplified pretreatment of $\mathrm{W}$ (grain diameter of $1.16 \mu \mathrm{m}$ ) and $\mathrm{TiC}$ (grain diameter of $500 \mathrm{~nm}$ ) was performed before electroless plating to produce a surface with catalytic activity. The produced $\mathrm{W}$ and $\mathrm{TiC}$ powders from simplified pretreatment were placed in a pre-made $\mathrm{Cu}$ plating solution for electroless plating $\mathrm{Cu}$. The $\mathrm{W}-30 \mathrm{Cu} / \mathrm{TiC}$ composite powders were compacted into $40 \mathrm{~mm} \times 8 \mathrm{~mm}$ dimension under pressure of $400 \mathrm{MPa}$ by a tablet machine. The as-reserved green samples were sintered at $1300{ }^{\circ} \mathrm{C}$ for 60 min in a flowing hydrogen atmosphere.

FE-SEM was used to characterize the morphology of the TiC powders before and after simplified pretreatment and $\mathrm{W}-30 \mathrm{Cu} / \mathrm{TiC}$ composite powder after electroless plating. The relative density of $\mathrm{W}-30 \mathrm{Cu} / \mathrm{TiC}$ composites were measured based on the Archimedes' principle. Vickers micro-hardness test and compression test composite materials were used to characterize the mechanical properties of $\mathrm{W}-30 \mathrm{Cu} / \mathrm{TiC}$ composites.

\section{Results and Discussion}

\subsection{Characterization of powders}

Chemical deposition on the surface of the powder is related to the catalytic capability of the plated surface. Considering the chemical inertness of $\mathrm{W}$ and $\mathrm{TiC}$ particles, $\mathrm{W}$ and TiC powders were pretreated to form the surface with good catalytic activities. To compare the changes in morphology after pretreatment, Fig.1a shows the surface morphology of the original $\mathrm{TiC}$ powder prior to pretreatment. There are no obvious defects on the surface of the original $\mathrm{TiC}$ particles. Fig.1b shows the surface morphology of the TiC powder after simplified pretreatment and some obvious steps on the surface. Catalytic capability is exhibited during activation. The activation on the surface of the solid is related to the number of active centers on the solid surface. These centers pertain to surface defects, such as step (e.g., obvious steps on the surface of the TiC powder after simplified pretreatment). These positions easily adsorb foreign matter bonding. Conventional electroless plating does not produce ceramic powder with catalytic activation on the coated surface. The simplified pretreatment process forms obvious steps on the surface of $\mathrm{TiC}$ powder after simplified pretreatment (Fig.1b). The existence of surface steps in TiC powders increases their specific surface areas and surface catalytic activities remarkably. These features are beneficial to the adsorption, nucleation, and growth of $\mathrm{Cu}$ particles during electroless plating.

In electroless deposition, metal ions are reduced to metal by the action of chemical reducing agents which are simple electron donors. The metal ions are electron acceptors that

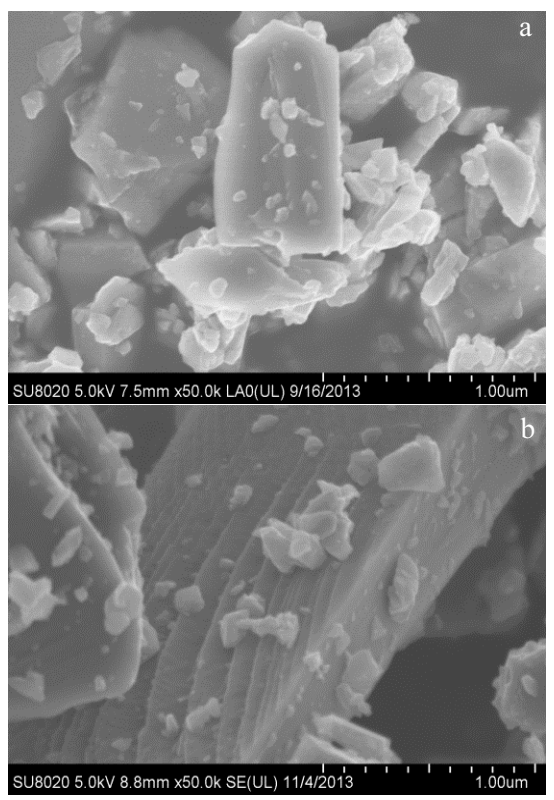

Fig. 1 FE-SEM morphologies of original TiC powders (a) and TiC powders after pretreatment (b) 
react with electron donors. FE-SEM micrographs of $\mathrm{W}$ and TiC complex powders after electroless $\mathrm{Cu}$ plating through simplified pretreatment are displayed in Fig. 2. The $\mathrm{Cu}$ coating on the surface of $\mathrm{W}$ and $\mathrm{TiC}$ particles shows a cell structure and uniform distribution. Almost no $\mathrm{Cu}$ uncoated particles are developed. The active surface enhances the wettability of the powders in aqua solutions of metalion species. The $\mathrm{Cu}^{2+}$ ions in the electroless plating solution are dispersed on the activated catalytic surface of the $\mathrm{W}$ and TiC powders. Hydrogen bubbles are observed during plating. The reacting substance is adsorbed on the defective surface with catalytic activation to produce an oxidation-reduction reaction for depositing $\mathrm{Cu}$ grains. Subsequently, the $\mathrm{Cu}$ particles grow. Through this reaction, the $\mathrm{Cu}$ grains are adsorbed on the surface defect of $\mathrm{W}$ and TiC powders to nucleate and grow. Therefore, the surface steps of the pretreated $\mathrm{W}$ and $\mathrm{TiC}$ powders are the active centers of nucleation and growth of the $\mathrm{Cu}$ particles.

\subsection{Characterization of sintered samples}

Table 1 shows the relationship between relative density and $\mathrm{TiC}$ content in the composite. As the $\mathrm{TiC}$ content increases, the relative density decreases. This finding may be attributed to the following reasons. The density of TiC $\left(4.93 \mathrm{~g} / \mathrm{cm}^{3}\right)$ is lower than those of $\mathrm{W}$ and $\mathrm{Cu}$. Therefore, the density of the W-Cu composite decreases with the increased $\mathrm{TiC}$ content. The sintered process is performed at $1300^{\circ} \mathrm{C}$; however, the melting temperature of $\mathrm{Cu}$ is $1083^{\circ} \mathrm{C}$. During the sintering process, the $\mathrm{Cu}$ melt and become liquid. In liquid phase sintering, densification of the W-Cu composite depends mainly on the rearrangement of the $\mathrm{W}$ particles. However, the addition of $\mathrm{TiC}$ hinders the rearrangement of the $\mathrm{W}$ particles to a certain extent, thus affecting the densification of the composite. Therefore, the more content of $\mathrm{TiC}$ are added, the more rearrangement of the $\mathrm{W}$ particles are hindered. At high temperature, the wettability between $\mathrm{TiC}$ and $\mathrm{Cu}$ is poorer than that between $\mathrm{W}$ and $\mathrm{Cu}$. Therefore, with the increased $\mathrm{TiC}$ contents, relative density of the composite material decreases.

Fig. 3 shows the metallographic micrographs of the $\mathrm{W}-30 \mathrm{Cu} / \mathrm{TiC}$ composite. Fig. $3 \mathrm{a} \sim 3 \mathrm{c}$ show that the composites have uniform and homogenous microstructures with fine particles when the $\mathrm{TiC}$ content is within a certain range. The addition of $\mathrm{TiC}$ reduces the contact between $\mathrm{W}$ and $\mathrm{W}$, thus promoting the refinement of particles after sintering. However, the composite is characterized by the formation of agglomerated particles and $\mathrm{Cu}$ pools when the $\mathrm{TiC}$ content is $2 \mathrm{wt} \%$ (Fig. $3 \mathrm{~d}$ ). This characterization may be ascribed to the poor wetability between $\mathrm{TiC}$ and $\mathrm{Cu}$. Consequently, the increase of $\mathrm{TiC}$ content hinders the flow of $\mathrm{Cu}$ liquid, resulting in a sintered bulk with composition segregation and low density.

Fig. 4 shows the FE-SEM morphologies of the fractured $\mathrm{W}-30 \mathrm{Cu} / \mathrm{TiC}$ composites. Some thin $\mathrm{Cu}$ layers exist as a

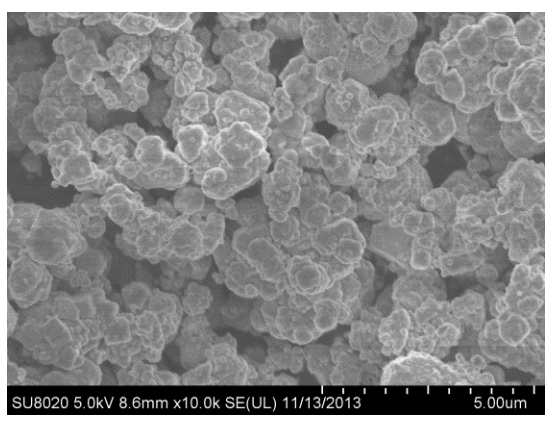

Fig. 2 FE-SEM morphology of the $\mathrm{W}$ and TiC complex powders after electroless $\mathrm{Cu}$ plating

Table 1 Relative density of $\mathrm{W}-30 \mathrm{Cu} / x \mathrm{TiC}$ composite

\begin{tabular}{cccccccc}
\hline$x$ & 0 & 0.25 & 0.5 & 1 & 2 & 3 & 4 \\
\hline Density/\% & 97.58 & 94.68 & 92.43 & 88.28 & 83.38 & 82.40 & 78.84 \\
\hline
\end{tabular}

network between $\mathrm{W}$ and $\mathrm{TiC}$ particles, and the network becames more intact with the TiC content increased to 1 wt $\%$ (Fig.4a 4d). TiC served the role of dispersion strengthening. However, the network becomes discontinues with the TiC content increasing to $2 \mathrm{wt} \%$. It is ascribed to the reinforcing particles which start to gather on the grain boundary with the $\mathrm{TiC}$ content increasing to $2 \mathrm{wt} \%$, which significantly reduces the bonding strength between particles. And some voids and holes in the cross section are found in the $\mathrm{W}-30 \mathrm{Cu}-2 \mathrm{TiC}$ ( $\mathrm{wt} \%$ ) composites with very low density.

The electrical conductivity, Vickers microhardness and the room temperature compressive strength of $\mathrm{W}-30 \mathrm{Cu} / x \mathrm{TiC}$ composites are shown in Table 2. As the TiC content increases, the electrical resistivity of $\mathrm{W}-30 \mathrm{Cu} / x \mathrm{TiC}$ composites also increases. This change in the values may be attributed to the electrical conductivity of $\mathrm{TiC}$ which is lower than those of $\mathrm{W}$ and $\mathrm{Cu}$. Despite the electrical conductivity decreasing, when the TiC content is $1 \mathrm{wt} \%$, the electrical conductivity (as percent of the International Annealed Copper Standard) of the composite reaches $49.78 \%$, which is higher than the national standard value (electrical conductivity of $\mathrm{GB} / \mathrm{T} 8320-2003$ is $42 \%$ ) of $18.53 \%$. However, when the $\mathrm{TiC}$ content is $4 \mathrm{wt} \%$, the electrical conductivity of the composite reaches $45.61 \%$, which is higher than the national standard value of $8.60 \%$. And the Vickers microhardness of composite increases with the $\mathrm{TiC}$ content increasing. This finding may be attributed to that the hardness of $\mathrm{TiC}$ is higher than those of $\mathrm{W}$ and $\mathrm{Cu}$, and the addition of $\mathrm{TiC}$ particle reduces the connection between the $\mathrm{W}$ and $\mathrm{W}$ particles. As Table 2 shows, when the TiC content is less than $1 \mathrm{wt} \%$, the compressive strength of the composite increases with the $\mathrm{TiC}$ content increasing. 


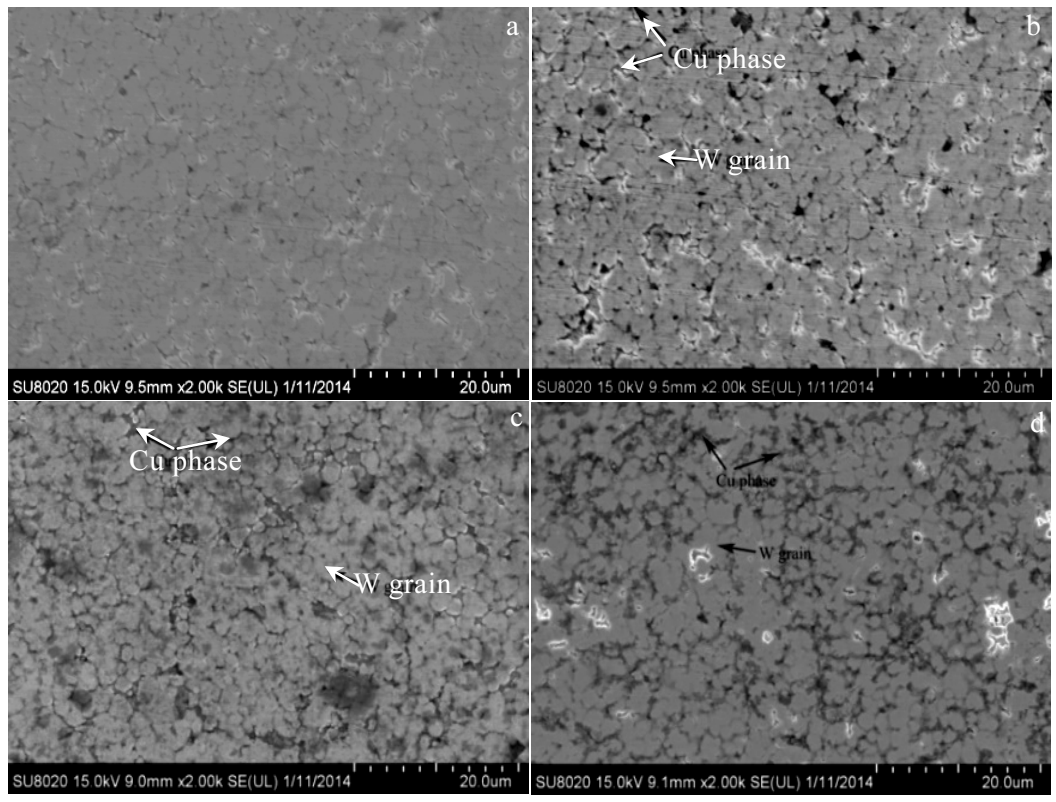

Fig. 3 FE-SEM micrographs of W-30Cu/ $x$ TiC composites: (a) $x=0$, (b) $x=0.5$, (c) $x=1$, and (d) $x=2$

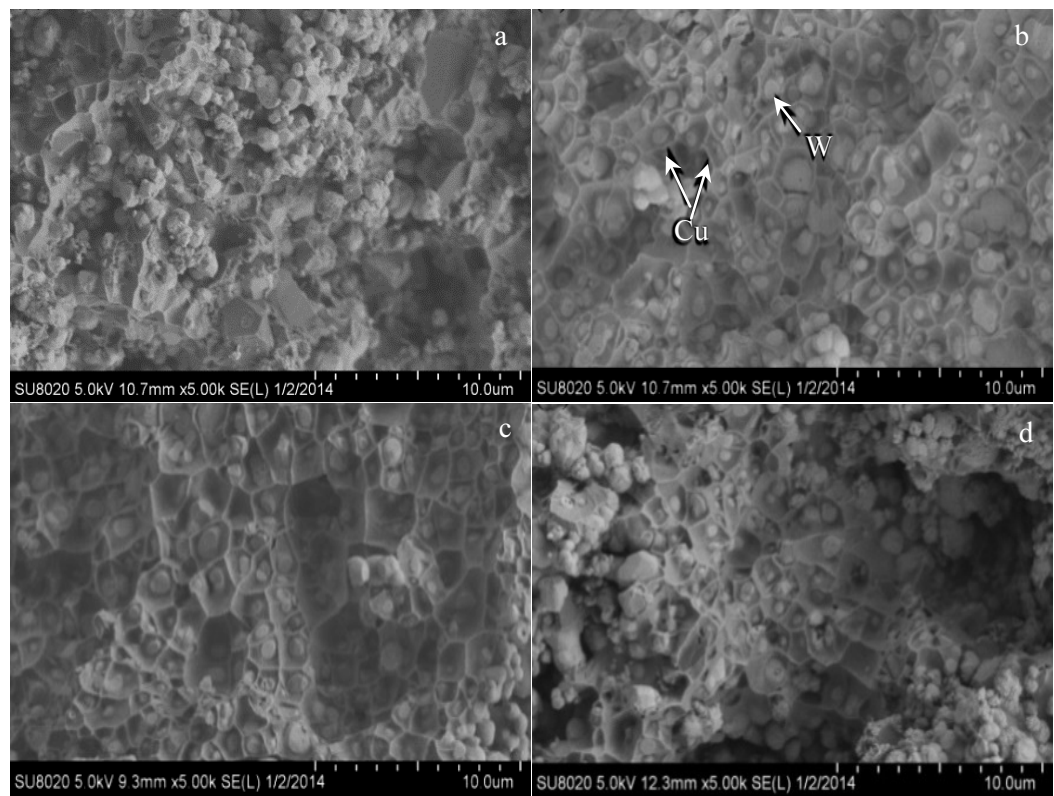

Fig. 4 FE-SEM morphologies of the fractured W-30Cu/ $x$ TiC composites: (a) $x=0$, (b) $x=0.5$, (c) $x=1$, and (d) $x=2$

It is attributed to that the network becomes more intact, and the composite has uniform and homogenous microstructures with fine particles with the $\mathrm{TiC}$ content increasing to $1 \mathrm{wt} \%$. These feature makes the compressive strength increase. However, when the TiC content is more than $1 \mathrm{wt} \%$, the compressive strength of the composite decreases substantially. This phenomenon is ascribed to the reinforcing particles gathering on the grain boundary with the $\mathrm{TiC}$ content increasing to $2 \mathrm{wt} \%$, which significantly reduces the bonding strength between particles. The addition of TiC particle to the composite decreases their density, and
Table 2 Electrical conductivity, microhardness (HV) and the room temperature compressive strength of $\mathrm{W}-30 \mathrm{Cu} /$ $x \mathrm{TiC}$ composites

\begin{tabular}{cccc}
\hline$x$ & Conductivity/\% & HV/MPa & Strength/MPa \\
\hline 0 & 59.13 & 3584 & 447.3 \\
0.25 & 51.65 & 4947 & 523.6 \\
0.5 & 51.12 & 6289 & 602.4 \\
1 & 49.78 & 6852 & 847.6 \\
2 & 47.45 & 7402 & 404.2 \\
3 & 46.52 & 7947 & 321.7 \\
4 & 45.61 & 8465 & 250.6 \\
\hline
\end{tabular}


some voids and holes are presented in the $\mathrm{W}-30 \mathrm{Cu}-2 \mathrm{TiC}$ composite.

\section{Conclusions}

1) $\mathrm{W}-30 \mathrm{Cu} / \mathrm{TiC}$ composite powders with uniform structure are prepared by electroless plating with simplified pretreatment. W-Cu/TiC composites are fabricated via powder metallurgy.

2) The $\mathrm{TiC}$ content influences the comprehensive performance of the composite materials. Adding a certain amount of $\mathrm{TiC}$ content $(x \leq 1)$ increases the compressive strength and hardness of the composite effectively, while decreases their electrical conductivity.

3) When the $\mathrm{TiC}$ content is $1 \mathrm{wt} \%$, the electrical conductivity of the composite reaches $49.78 \%$, which is higher than the national standard of $18.53 \%$.

\section{References}

1 Chen P G, Shen Q, Luo G Q et al. Surf Coat Technol[J], 2016, 288: 8

2 Huang L M, Luo L M, Ding X Y et al. Powder Technol[J], 2014, 258: 216

3 Wei X X, Tang J C, Ye N et al. J Alloy Compd[J], 2016, 661: 471

4 Zhou Q, Chen P W. J Alloy Compd[J], 2016, 657: 215

5 Zhu X Y, Zhang J, Chen J L et al. Rare Metal Mater Eng[J], 2015, 44(11): 2661

6 Yang X H, Liang S H, Wang X H et al. Int J Refract Met $H[\mathrm{~J}]$, 2010, 28: 305

7 Mohapatra S, Mishra D K, Singh S K et al. Powder Technol [J], 2013, 237: 41
8 Song G M, Wang Y J, Zhou Y et al. Int J Refract Met $H[\mathrm{~J}]$, 2003, 21: 1

9 Kitsunai Y, Kurishita H, Kayan H et al. J Nucl Mater[J], 1999, 271-272: 423

10 Safari J, Chermahini M D, Akbari G H et al. Powder Technol [J], 2013, 234: 7

11 Maneshian M H, Simchi A J Alloy Compd[J]. 2008, 463: 153

12 Rivera Olvera J N, Gutiérrez Paredes G J, Serrano A R et al. Powder Technol[J], 2015, 271: 292

13 Sha W, Wu X, Keong K G. Electroless Copper and Nickel-Phosphorus Plating: Processing[M]. Cambridge, UK: Characterisation and Modelling, Woodhead Publishing, 2011

14 Sudagar J, Lian J S, Sha W. J Alloy Compd[J], 2013, 571: 183

15 Ahn J G, Kim D J, Lee J R et al. Surf Coat Technol[J], 2006, 201: 3793

16 Chen Y J, Cao M S, Xu Q et al. Surf Coat Technol[J], 2003, 172: 90

17 Shi G M, Han J K, Zhang Z D et al. Surf Coat Technol[J], 2005, 195: 333

18 Jafaria M, Enayatia M H, Salehia M et al. Surf Coat Technol [J], 2013, 235: 310

19 Luo L M, Wu Y C, Li J et al. Surf Coat Technol[J], 2011, 206: 1091

20 Uysal M, Karslioğlu R, Alp A et al. Ceram Int [J], 2013, 39: 5485

21 Harizanov O A, Stefchev P L, Iossifova A. Mater Let [J], 1998, 33: 297

22 Luo L M, Lu Z L, Tan X Y et al. Powder Technol[J], 2013, 249: 431

\title{
$\mathrm{TiC}$ 含量对 $\mathrm{W}-30 \mathrm{Cu} / \mathrm{TiC}$ 复合材料显微结构和性能的影响
}

\author{
谌景波 ${ }^{1}$, 黄丽枚 ${ }^{1}$, 罗来马 ${ }^{1,2}$, 处 祥 $^{1,2}$, 吴玉程 ${ }^{1,2}$ \\ (1. 合肥工业大学, 安徽 合肥 230009) \\ (2. 安徽省粉末冶金工程技术研究中心，安徽 合肥 230009)
}

\begin{abstract}
摘 要: 经简化预处理后, 采用化学法制得 $\mathrm{W}-30 \mathrm{Cu} / x \mathrm{TiC}(x=0 \sim 4$, 质量分数 $\%)$ 复合粉末, 在 $400 \mathrm{MPa}$ 压力下, 将制得的复合粉末压制 成毛坏块体试样, 随后在 $1300{ }^{\circ} \mathrm{C}$ 下烧结 $1 \mathrm{~h}$ 制得块体复合材料试样。采用场发射扫描电镜来表征原始 $\mathrm{W}$ 和 $\mathrm{TiC}$ 粉末、预处理后的 $\mathrm{W}$ 和 $\mathrm{TiC}$ 粉末、化学法制得的 $\mathrm{W}-30 \mathrm{Cu} / x \mathrm{TiC}(x=0 \sim 4)$ 复合粉末的显微形貌，以及制得的 $\mathrm{W}-30 \mathrm{Cu} / \mathrm{TiC}$ 复合材料的显微结构。对不同 $\mathrm{TiC}$ 含 量对 $\mathrm{W}-30 \mathrm{Cu} / \mathrm{TiC}$ 复合材料性能（相对密度、硬度、导电性和抗弯强度等）进行研究。结果表明：对简单预处理后的 $\mathrm{W} 、 \mathrm{TiC}$ 粉末化 学镀 $\mathrm{Cu}$ 所获得的 $\mathrm{W}-30 \mathrm{Cu} / \mathrm{TiC}$ 复合粉末的显微结构均匀。 $\mathrm{TiC}$ 含量低于 $1 \%$ 时, $\mathrm{W}-30 \mathrm{Cu} / \mathrm{TiC}$ 复合材料的抗弯强度和硬度随 $\mathrm{TiC}$ 含量的 增加而显著增大。而导电性则随 $\mathrm{TiC}$ 含量增加而减小, 但仍高于国家标准值。添加一定量的 $\mathrm{TiC}$ 有利于获得综合性能较好的 $\mathrm{W} 30 \mathrm{Cu} / \mathrm{TiC}$ 复合材料。
\end{abstract}

关键词：简单预处理；化学镀； W-Cu/TiC 复合材料；性能

作者简介: 谌景波, 男, 1991 年生, 硕士生, 合肥工业大学材料科学与工程学院, 安徽 合肥 230009, 电话: 0551-62901012, E-mail: metal2007@tom.com 